\title{
Revised stratigraphy of the Cookson Group in eastern Maine and southwestern New Brunswick: an alternate view
}

\author{
Allan Ludman \\ Department of Geology, Queens College, City University of New York, Flushing, New York 11367, U.S.A. \\ and \\ Maine Geological Survey, State House Station No. 22, Augusta, Maine 04333, U.S.A.
}

Date Received November 21, 1990

Date Accepted March 12, 1991

\begin{abstract}
Fossil evidence reported by Fyffe and Riva (1990) requires inversion of the stratigraphic succession originally proposed for the St. Croix Terrane (Ludman, 1987). Other suggested revisions, however, are not in accord with structural and sedimentologic data in eastern Maine. Comparison of structural histories indicates that the Pocomoonshine Lake and Digdeguash formations are more appropriately part of the Fredericton Belt than of the St. Croix Terrane as suggested by Fyffe and Riva (1990). An alternate view of the stratigraphic and tectonic relationships between the St. Croix Terrane and Fredericton Belt includes the following changes: the Pocomoonshine Lake Formation, originally assigned to the St. Croix Terrane, is now considered to be the oldest unit of the Fredericton Belt, lying conformably below the Digdeguash Formation; a late Acadian thrust fault is thought to have transported the St. Croix Terrane westward over the Fredericton Belt; subsequent high-angle dip-slip and strike-slip faulting have obscured original relationships-these faults now form the boundary between the two terranes in southeastem Maine.
\end{abstract}

Le témoignage apporté par les fossiles qu'ont signalés Fyffe et Riva (1991) nécessite une inversion de la séquence stratigraphique proposée à l'origine pour la Lanière de St. Croix (Ludman, 1987). Cependant, les autres révisions, ayant été suggérées sont en contradiction avec les données structurales et sédimentologiques en provenance du Maine oriental. La comparaison des antécédents structuraux indique qu'il est plus adéquat d'incorporer les formations de Pocomoonshine Lake et de Digdeguash à la Ceinture de Fredericton qu'à la Lanière de St. Croix comme l'ont suggéré Fyffe et Riva (1991). Une conception de rechange ayant trait aux relations stratigraphiques et tectoniques entre la Lanière de St. Croix et la Ceinture de Fredericton englobe les changements suivants: la Formation de Pocomoonshine Lake, rattachée à l'origine à la Lanière de St. Croix, est maintenant tenue pour étant la plus vieille unité au sein de la Ceinture de Fredericton, recouverte en concordance par la Formation de Digdeguash; un chevauchement tardi-acadien est envisagé comme ayant transporté la Lanière de St. Croix vers l'ouest par-dessus la Ceinture de Fredericton; le jeu subséquent de décrochements et de failles à rejet selon leur pendage, tous fortement inclinés, a obscurci les rapports originaux - ces failles constituent maintenant la frontière entre ces deux lanières dans le sud-est du Maine.

[Traduit par le joumal]

\section{INTRODUCTION}

The St. Croix Terrane of eastern Maine and southwestern New Brunswick is a narrow but tectonically important lithotectonic block (Fig. 1) composed of Cambrian(?) to Middle Ordovician strata. Its relationships with adjacent Silurian to Early Devonian terranes (Coastal Volcanic/Mascarene Belt, Fredericton Belt) and with potential pre-Silurian correlatives across strike (Saint John Group of the Avalon Terrane to the east, Tetagouche Group of the Miramichi Terrane to the west) are critical to understanding the Paleozoic configurations of ancestral North America and the Avalon Terrane with which it collided during the Late Silurian-Early Devonian Acadian Orogeny. Fyffe and Riva (1990) have presented an important revision of the stratigraphy originally proposed for the Cambrian-Ordovician Cookson Group of the St. Croix Terrane (Ludman, 1987). Their discovery of Middle Caradocian graptolites in the Kendall Mountain Formation (Fyffe, 1989; Fyffe and Riva, 1990, p. 274) pinpointed the age of that formation and required overturning the sequence that had been proposed originally (left and centre columns of Table 1). This revision has wide-ranging importance in local stratigraphic correlation and regional tectonic modeling, and is a valuable contribution to our understanding of the accretion history of the Northern Appalachians.

Other aspects of the interpretation of Fyffe and Riva (1990), however, are more debatable. Bedrock exposure within the St. Croix Terrane is poor in both Maine and New Brunswick, generally amounting to $1 \%$ or less of the outcrop area of the belt. Sparse exposure, a complex polydeformation history within the terrane, and variable relationships along its contacts with adjacent tracts prevent unequivocal resolution of local stratigraphic problems. 


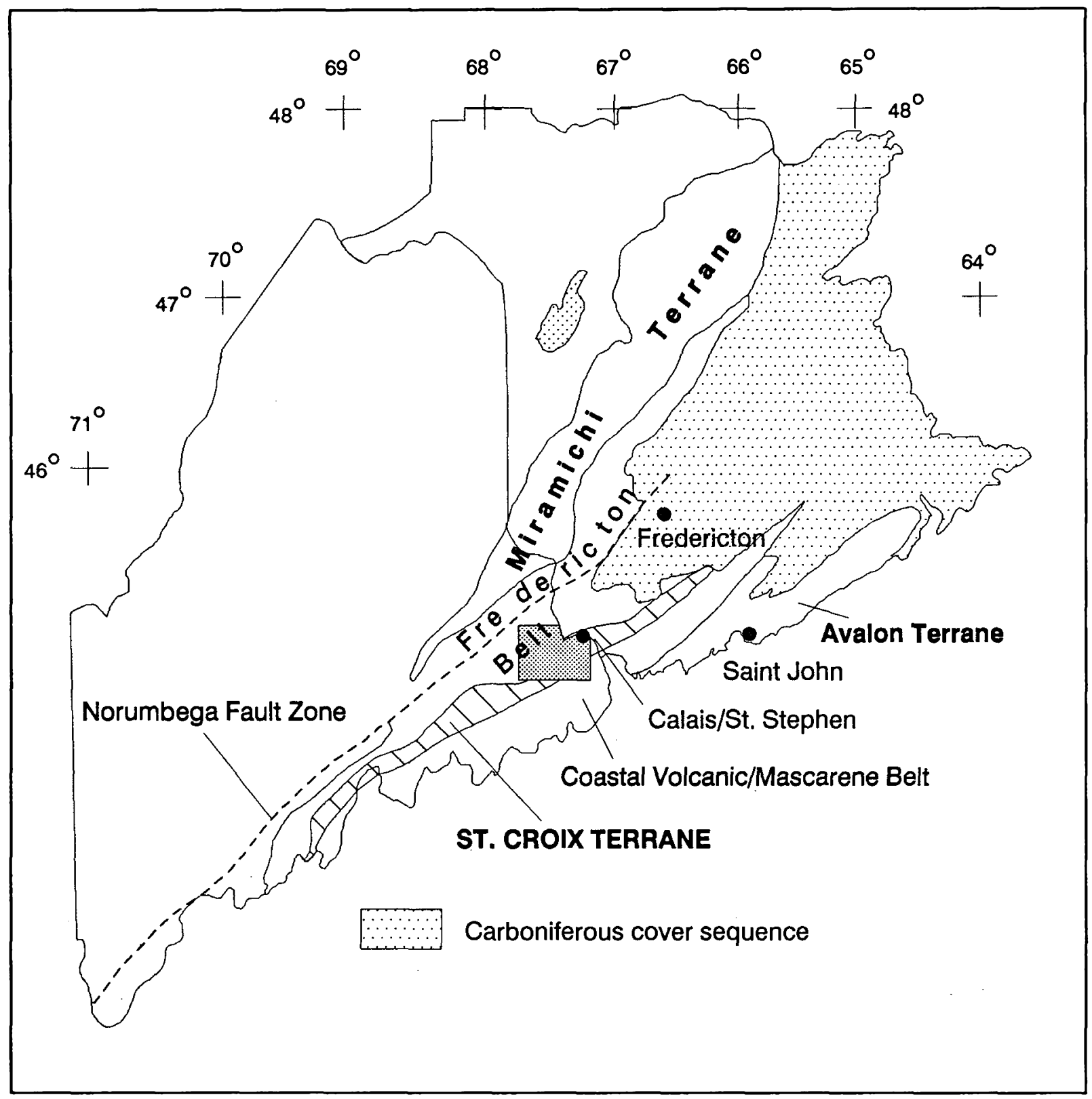

Fig. 1. Simplified tectonic map of eastem Maine and New Brunswick showing relationships of the St. Croix Terrane to adjacent terranes. Pre-Silurian terranes are indicated by boldface type. Shaded area marks location of Calais and Big Lake quadrangles shown in Figure 2.

The purpose of this paper is to present an alternate view of the stratigraphy of the Cookson Group and adjacent strata of the Fredericton Belt (right-hand column of Table 1) based on detailed mapping from 1974 to 1986 in the Calais and Big Lake 15 minute quadrangles of eastern Maine. My revised version incorporates the new fossil age control and inversion of the proposed section suggested by Fyffe and Riva (1990). It differs in its interpretation of the Digdeguash and Pocomoonshine Lake formations as components of the Fredericton Belt rather than as parts of the St. Croix Terrane, and the remainder of this paper will discuss the relationships that led to this conclusion.

\section{Association of the Pocomoonshine Lake Formation with the Digdeguash Formation}

The Pocomoonshine Lake Formation is a package of thinbedded carbonaceous and noncarbonaceous slates, with subordinate siltstone and fine-grained sandstone commonly present as the bases of graded beds (Ludman, 1987). Its lithic similarity to pelites intercalated with wackes and arenites of the Woodland and Kendall Mountain formations led to its inclusion in the Cookson Group, originally as the oldest formation (Ludman, 1987) but more recently as the youngest (Fyffe and Riva, 1990). 
Table 1. Evolution of Cookson Group stratigraphy. Asterisks denote fossil age control of stratigraphic units. Dashed lines indicate tectonic contacts. Ruled area denotes inferred unconformity; stippling indicates absent section.

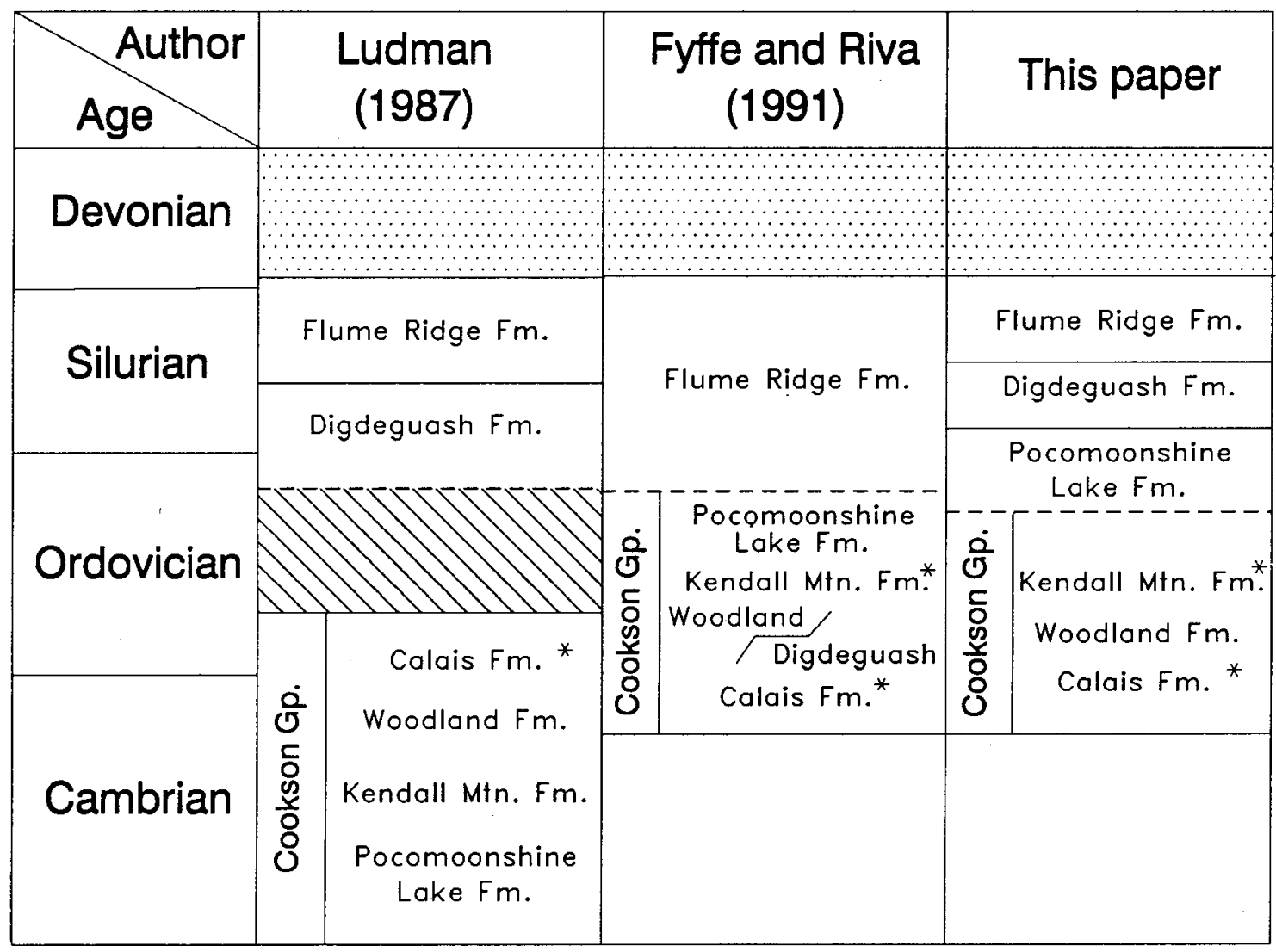

Re-examination of contact relationships between the Pocomoonshine Lake and adjacent Kendall Mountain and Digdeguash formations has yielded sedimentological and structural evidence that indicate its affiliation with the Fredericton Belt rather than the Cookson Group of the St. Croix Terrane.

At extremely low-water stages, small exposures in the southeastem part of Pocomoonshine Lake (Fig. 2), normally under water, reveal interbedding of the pelite of the Pocomoonshine Lake Formation with wackes and fine-grained grits identical to those of the Digdeguash Formation exposed on the opposite shore nearby. In all other places in its outcrop belt in Maine, the Digdeguash is devoid of carbonaceous, rusty-weathering pelites. Here, the relationship is interpreted as a gradational contact between the two formations. Unfortunately, the nearest facing evidence is about $100 \mathrm{~m}$ from the gradational zone; there, graded beds in the Digdeguash Formation face northwestward, suggesting, but by no means proving, that the Digdeguash lies above the Pocomoonshine Lake.

By itself, this does not contradict the stratigraphy proposed by Fyffe and Riva (1990). If the Digdeguash and Woodland formations are temporal equivalents as they have proposed, this would make the Pocomoonshine Lake correlative with the Calais Formation, a possibility considered during my early work in the St. Croix Terrane but rejected because of lithologic and structural differences. A facies change less dramatic than that required by the Woodland-Digdeguash equivalence proposed by Fyffe and
Riva (1990) could readily explain the lithologic differences. All parties now agree that the Digdeguash and Pocomoonshine Lake formations have a conformable depositional contact rather than the tectonic contact implied by earlier interpretations (e.g., Ludman, 1987).

The critical question is whether the Digdeguash and Pocomoonshine Lake formations belong to the St. Croix Terrane, as proposed by Fyffe and Riva (1990), or should be viewed as parts of the Fredericton Belt as suggested here. Both lithologic and structural evidence in Maine suggest the latter.

\section{Lithologic comparison of the Digdeguash and Woodland formations}

The correlation of the Digdeguash and Woodland formations proposed by Fyffe and Riva (1990) requires a significant facies change for which there is no evidence in eastern Maine. The two units do exhibit some similarities. Both are composed of interbedded wacke and pelite, and both are noncalcareous with the exception of one or two horizons and a few beds containing calcite pods. Wacke and slate are present in nearly equal proportions in both units.

There are significant differences. The Woodland Formation is for the most part a homogeneous unit composed of rhythmically interbedded and well-graded quartzofeldspathic wacke and slate. The wacke is generally fine to medium grained and grain 


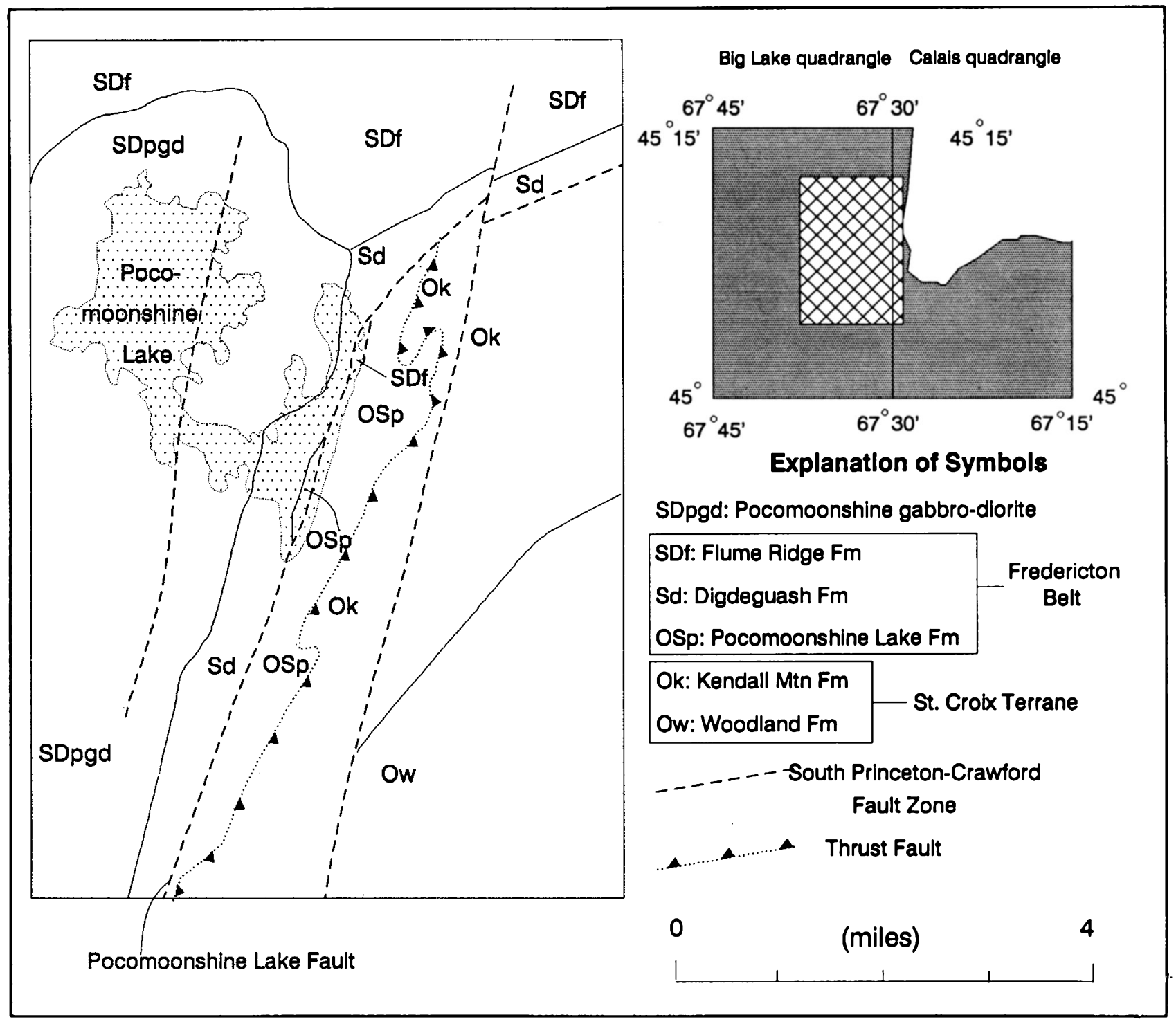

Fig. 2. Contact relationships between the St. Croix Terrane and Fredericton Belt in southeastern Maine. Shaded pattern on inset corresponds to shaded area in Figure 1. Cross-hatched pattem on inset shows location of geologic map (to left) within Calais and Big Lake quadrangles.

size within a single bed is generally uniform; graded beds reflect a compositional gradation more than grain size changes. Two kinds of slate are present in nearly equal proportions: a dark gray to black, highly carbonaceous variety and a medium gray, noncarbonaceous type. All Woodland exposures in Maine are moderately to highly sulfidic, with pyrite present in both wacke and slate. This results in a well-developed iron oxide weathering rind.

In contrast, the Digdeguash Formation is much more heterogeneous. Beds are more irregular in thickness, displaying none of the rhythmicity characteristic of the Woodland. Indeed, the Digdeguash exhibits a much greater heterogeneity in both bed thickness (a few centimetres to a few metres) and lithic proportions; well-graded psammite/pelite sequences, massive pelite, massive wacke, or massive conglomerate comprise zones throughout its outcrop belt in eastern Maine. Digdeguash psammites are most commonly lithic wackes with both polymineralic and monomineralic rock fragments (Ludman, in press). Such clasts are identifiable even in fine-grained sandstones comparable in grain size to those of the Woodland Formation. Black carbonaceous pelites are unknown in the Digdeguash Formation in Maine. Finally, pyrite is rare in both wackes and slates of the Digdeguash Formation and the typical weathering rind is buff to pale gray due to alteration of feldspars and feldspathic lithic fragments.

Bulk chemical differences between Woodland and Digdeguash strata are emphasized by metamorphic assemblages in contact aureoles. At moderate grades the Woodland first develops cordierite in both pelite and wacke, and then cordieriteandalusite assemblages. At the same grades, Digdeguash hornfelses are totally devoid of cordierite.

Although some of the differences in bedding style and lithic homogeneity can be readily explained by a facies change, the 
lithic nature of the Digdeguash wackes and the difference in bulk chemical composition suggests that the Digdeguash and Woodland formations should not be equated. The final piece of evidence lies in the deformational histories of the formations.

\section{Structural criteria for assignment of the Digdeguash and Pocomoonshine Lake formations to the Fredericton Belt}

The Digdeguash and Pocomoonshine Lake formations are here assigned to the Fredericton Belt because their deformation history appears to be identical to that of the Flume Ridge Formation (which comprises most of the Fredericton Belt in eastern Maine) and markedly different from that of the adjacent Kendall Mountain and Woodland formations of the Cookson Group. Ludman (in press) and Ludman and Hill (in press) provide a detailed discussion of the deformation histories of the St. Croix Terrane and Fredericton Belt; only abrief summary will be given here.

Rocks assigned to the Cookson Group have experienced a complex polydeformation history that includes at least one episode of early recumbent folding, followed by later upright folding about northeast-trending hinge surfaces. Only the latter of these events is recorded in rocks considered to belong to the Fredericton Belt. This is clearly shown in stereonet plots of poles to bedding and cleavage in the two tracts (Fig. 3). The tight cluster of poles to both bedding and cleavage in the Fredericton rocks (lower part of Fig. 3) reflects the single penetrative deformation that affected the Flume Ridge, Digdeguash, and Pocomoonshine Lake formations. The attitude of bedding in these three formations rarely deviates by more than $15^{\circ}$ from vertical. This contrasts sharply with the wide spread exhibited by poles from the polydeformed St. Croix Terrane.

The transition from singly folded, steeply dipping rocks of the Fredericton Belt to polydeformed rocks exhibiting a wide range of attitudes in the St. Croix Terrane is abrupt in eastern Maine, occurring at an inferred thrust fault east of Pocomoonshine Lake (Fig. 2). Later high-angle faulting has greatly modified the initial thrust relationships, and near-vertical faults of the

\section{Bedding}

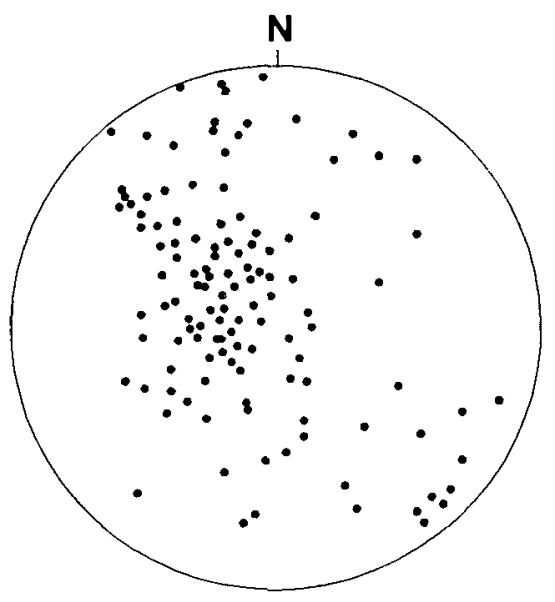

Cleavage

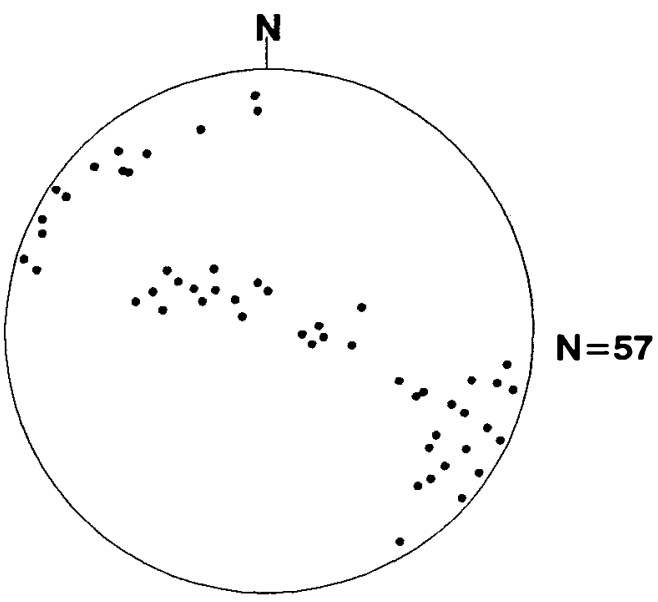

St. Croix Terrane

(Woodland and Kendall Mountain formations)
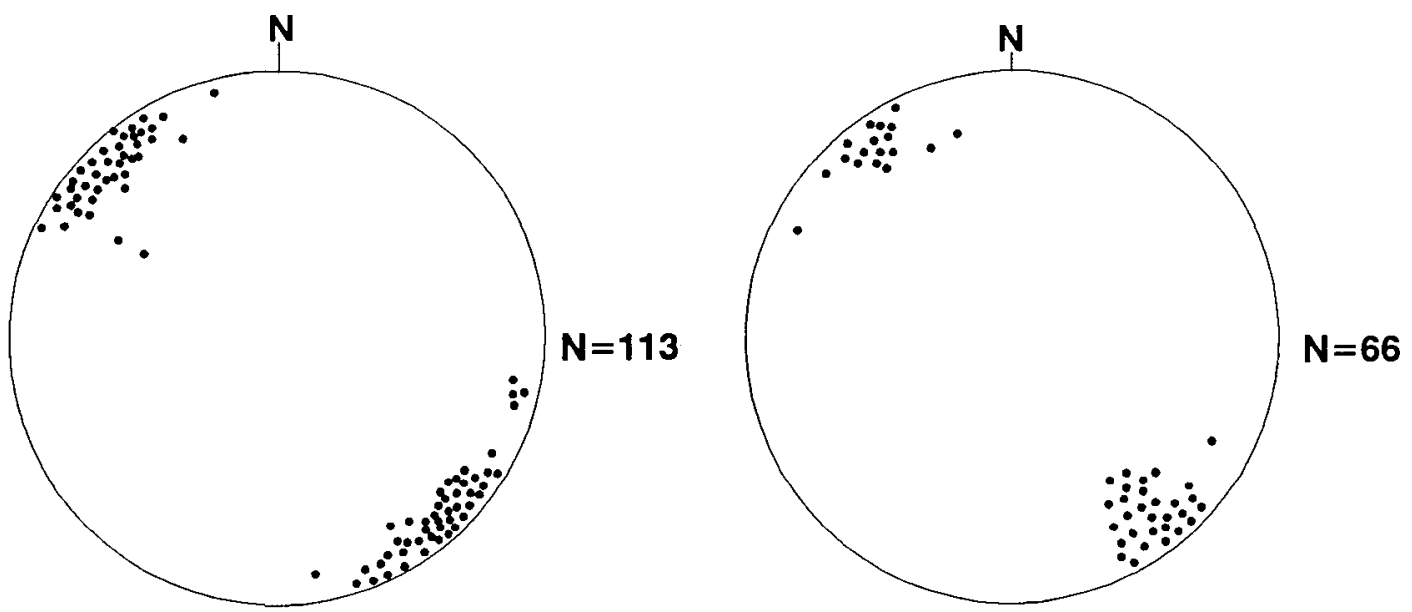

Fredericton Belt

(Flume Ridge, Digdeguash, and Pocomoonshine Lake formations)

Fig. 3. Stereonet comparison of poles to bedding and cleavage for rocks of the St. Croix Terrane and Fredericton Belt (as defined in this paper). 
South Princeton-Crawford fault zone locally separate Digdeguash and Pocomoonshine Lake rocks from those of the Kendall Mountain and Woodland formations (Fig. 2). Thus, the contact between Fredericton Belt and St. Croix rocks in eastern Maine is everywhere a fault.

Present relationships evolved in a series of steps shown schematically in Figure 4. Kendall Mountain and Woodland strata were isoclinally folded about what are now recumbent hinge surfaces (F1). In most of eastern Maine, the Cookson Group is exposed on the upright limb of a major recumbent F1 antiform. Inverted later folds indicate that the lower limb crops out in a few places, generally near blocks uplifted along late north-trending faults. It is difficult to date F1 precisely. It can be no older than the Middle Caradocian age of the Kendall Mountain Formation, and no younger than late Silurian, the age of the Oak Bay and Waweig formations of the Coastal Volcanic belt which lie unconformably above the Cookson Group in southern New Brunswick (Ruitenberg, 1967). An unconformity is also inferred to have at one time separated the Pocomoonshine Lake Formation from the St. Croix Terrane in the area shown in Figures 1 and 3 (Ludman, in press).
Following deposition of the Pocomoonshine Lake, Digdeguash, and Flume Ridge formations, the Fredericton Belt and St. Croix Terrane were folded about northeast-trending upright hinge surfaces, producing open folds (F2) attributed to the Acadian Orogeny. F1 folds, foliation, and cleavage in the St. Croix Terrane were deformed during this event. Following F2, or in what may have been a continuation of $F 2$ compression, the subhorizontal Kendall Mountain and Woodland formations were thrust westward over the Fredericton Belt (Fig. 4a). Evidence for this thrusting includes asymmetric folds with consistent westvergence widely distributed near the inferred fault, and smallscale thrusts visible in the type locality of the Woodland Formation (Ludman and Hill, in press). A gently east-dipping cleavage is well developed in Woodland and Kendall Mountain pelites, and is most prominent close to the fault.

Later uplift on the west side of the high-angle Pocomoonshine Lake Fault was followed by erosion that removed the overthrust sheet and exposed what had been the lower plate of the thrust (Fig. 4b, c). A weakly developed, gently east-dipping cleavage preserved in slates of the Pocomoonshine Lake Formation adjacent to the Pocomoonshine Lake Fault is the only record

a)Acadian thrusting of St. Croix terrane westward over Fredericton Trough

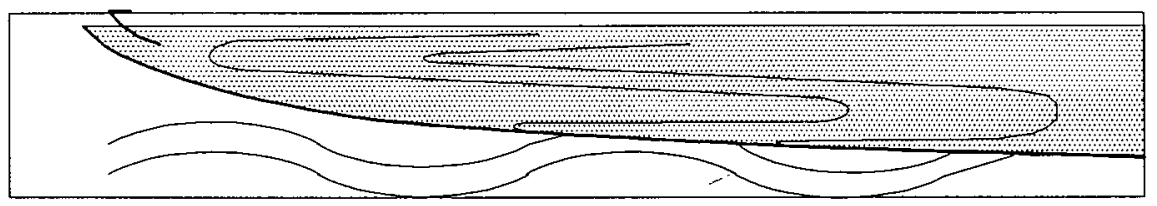

b)Late Acadian motion on South Princeton-Crawford Fault Zone

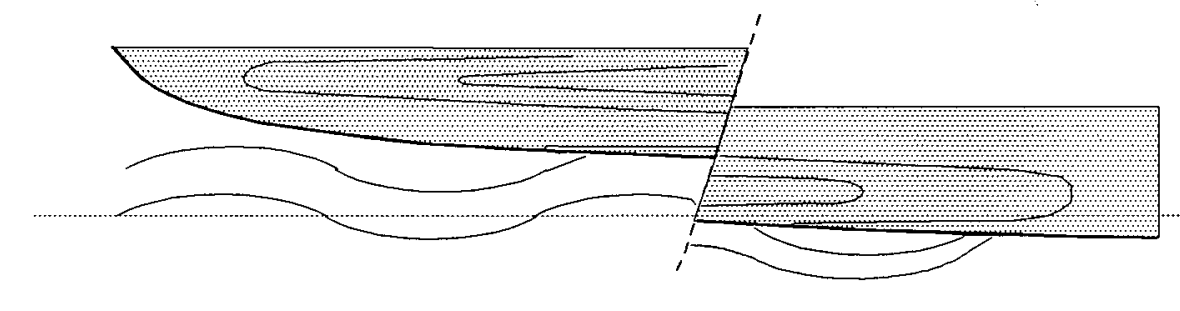

c)Erosion to expose present relationships

Fredericton Trough

St. Croix Terrane

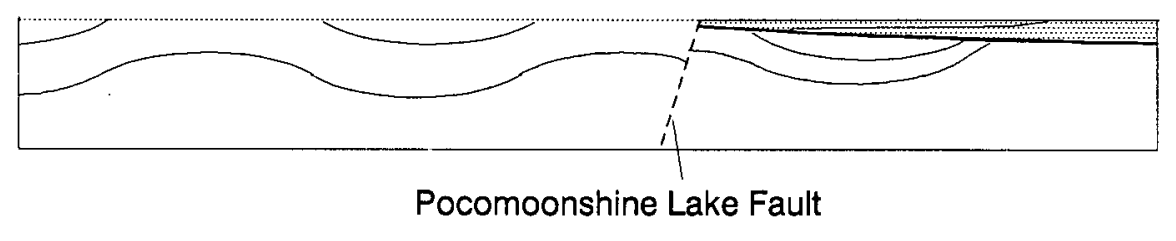

Fig. 4. Evolution of the contact between the St. Croix Terrane (patterned) and Fredericton Belt (unpatterned) in southeastern Maine. Dotted line in (b) represents present erosional surface. 
of the thrusting on the lower plate. A small sliver of Flume Ridge Formation caught up in the high-angle faulting is preserved along the east shore of Pocomoonshine Lake (Fig. 2). Later sinistral strike-slip reactivation of branches of the South PrincetonCrawford Fault Zone further disrupted original relationships.

Local structural relationships are somewhat different in New Brunswick just a few kilometers to the east. The Digdeguash Formation near Moores Mills has been deformed in a series of southeast-vergent recumbent folds (Fyffe, personal communication, 1989) designated as late (F2) folds by Ruitenberg (1967). These southeast-vergent folds have not been observed anywhere in Maine. F2 and later thrusting are interpreted as mid- and late-Acadian events (Ludman, in press); uplift on faults such as the South Princeton-Crawford Fault Zone and later strike-slip motion are thought to be final adjustments to the collision between the Avalonian and North American plates which caused that orogeny. The folds near Moores Mills appear to be developed only locally, and probably mark local transpression during the final phase of the Acadian cycle rather than the F1 folding exhibited by the Cookson Group.

\section{Flume Ridge-Digdeguash contact relationships}

In New Brunswick, a quartz-filled zone of brittle deformation separates the Digdeguash and Flume Ridge formations, and is used as evidence to suggest that the two units belong to different lithotectonic blocks (Fyffe, 1989; Fyffe and Riva, 1990). Glacial deposits mask this contact in eastern Maine but it appears to be a gradational contact rather than a fault in the Big Lake and Calais quadrangles. The Digdeguash Formation is almost entirely noncalcareous, but lithic wackes and conglomerates adjacent to the contact with calcareous wackes of the Flume Ridge Formation have slightly to moderately calcareous matrixes. In addition, pelitic horizons are rare in the Flume Ridge Formation in the Big Lake quadrangle, but gray laminated slates identical to those of the adjacent Digdeguash Formation appear in the Flume Ridge near the contact.

Ruitenberg (1967) reported that the Flume Ridge Formation lies conformably above the Digdeguash. Facing evidence in Maine is inconclusive on this matter. Graded beds in the Digdeguash Formation closest to the Flume Ridge suggest the opposite relationship, but these are more than $50 \mathrm{~m}$ from the inferred position of the contact. Similarly equivocal evidence has been cited above for the contact between the Pocomoonshine Lake and Digdeguash formations. Based on this weak evidence, the stratigraphic sequence along the eastern margin of the Fredericton Belt in Maine is inferred to be that shown in Table 1.

\section{CONCLUSIONS}

Field mapping in southeastern Maine supports an interpretation of the stratigraphy of the St. Croix Terrane which differs from that suggested by Fyffe and Riva (1990) as well as from that originally proposed by Ludman (1987). The Pocomoonshine Lake Formation is now thought to belong to the Fredericton Belt with the Digdeguash and Flume Ridge formations, because of (1) apparently identical and relatively simple deformation histories, (2) differences with the more complex polydeformational history of the Cookson Group, and (3) an apparently gradational contact between the Digdeguash and Pocomosnshine Lake formations.

Original relationships between the St. Croix and Fredericton Belt terranes are clouded by several stages of faulting along their contact. Their much simpler structural evolution suggests that the Fredericton Belt strata were deposited after post-Middle Orodovician folding of the Cookson Group, or in a basin removed from the effects of that Ordovician tectonism. The former explanation is preferred. Following upright Acadian folding that accompanied suturing of the St. Croix Terrane to ancestral North America, rocks of the St. Croix Terrane were thrust westward over the Fredericton Belt. The contact was then further complicated by dip-slip separation along north-trending faults and later strikeslip reactivation of the same structures.

\section{ACKNOWLEDGEMENTS}

My fieldwork in eastern Maine has been supported by the Maine Geological Survey, under the direction of State Geologists Robert G. Doyle and Walter Anderson. Additional field and laboratory support has been provided by several PSC-BHE grants from the City University of New York Research Foundation. This manuscript has benefited greatly from comments and suggestions made by Art Ruitenberg and Peter Stringer.

FYFFE, L.R. 1989. Bedrock geology of the Moores Mills area, Charlotte County, New Brunswick. Edited by S.A. Abbott. In New Brunswick Department of Natural Resources and Energy, Minerals and Energy Division, Information Circular 89-2, pp. 28-39.

FYFFE, L.R. and RIVA, J. 1990. Revised stratigraphy of the Cookson Group of southwestern New Brunswick and adjacent Maine. Atlantic Geology, 26, pp. 271-275.

LUDMAN, A. 1987. Pre-Silurian stratigraphy and tectonic significance of the St. Croix Belt, southeastern Maine. Canadian Journal of Earth Sciences, 24, pp. 2459-2469.

In press. Bedrock geology of the Big Lake quadrangle, southeastern Maine. Maine Geological Survey Geologic Map Series GM-9, 54 p.

LUDMAN, A. and HILL, M. In press. Bedrock geology of the Calais quadrangle, southeastern Maine. Maine Geological Survey Geologic Map Series GM-10, 72 p.

RUTTENBERG, A.A. 1967. Stratigraphy, structure, and metallization, Piskahegan-Rolling Dam area, New Brunswick; Leidse Geologische Mededelingen, Part 40, pp. 79-120. 